\title{
A INFLUÊNCIA DO DIREITO PENAL SIMBÓLICO NO SURGIMENTO DOS SISTEMAS PENAIS PARALELOS E SUBTERRÂNEOS
}

THE INFLUENCE OF SYMBOLIC CRIMINAL LAW ON THE ESTABLISHMENT OF PARALLEL AND UNDERGROUND PENAL SYSTEMS

Carlos Henrique GASPAROTO1

Leonardo Machado ACOSTA²

ISSUE DOI: $10.21207 / 1983.4225 .558$

\section{RESUMO}

O objetivo geral deste trabalho diz respeito à influência que o Direito Penal Simbólico causa na geração e fortalecimento dos sistemas penais paralelos e subterrâneos. Para tanto, primeiramente foi estudado o Direito Simbólico como um todo, buscando perceber o porquê de sua utilização ser acentuada nos dias atuais; foi

\footnotetext{
${ }^{1}$ Promotor de Justiça do Ministério Público do Estado de São Paulo. Graduação em Direito na Faculdades Integradas de Itapetininga - Fundação Karnig Bazarian (1983). Mestrado em Direito pela Universidade de Franca (2000). Currículo Lattes: http://lattes.cnpq.br/4834784405130254.

${ }^{2}$ Graduando do curso de Direito pela Faculdade de Direito de Franca e estagiário no Ministério Público do Estado de São Paulo. Currículo Lattes: http://lattes.cnpq.br/6383552728471300. E-mail: leonardomachadoacosta@hotmail.com
} 
constatado que isto ocorre em razão da atual insegurança sofrida pela sociedade de risco, da intensificação do valor simbólico exercido pelas mídias e a exploração deste aspecto do referido ramo penal pelos discursos políticos. Este uso deturpado do Direito Penal Simbólico gera inúmeras consequências, como a corrupção da função penal real do Direito Penal influenciar negativamente na elaboração de políticas criminais e, como consequência fatal, o descrédito e a perda de legitimação do Direito Penal aos olhos de uma parcela da população. Com todos estes efeitos do mau uso do valor simbólico do ramo penal, foi possível traçar uma conexão entre esse e o surgimento e fortalecimento dos sistemas penais paralelos e subterrâneos, em que as pessoas buscam para si o jus puniendi estatal e aplicam condenações por conta própria. Ao final, foram verificados os danos que tudo isso causa à justiça brasileira, como fonte de inobservância de garantias e direitos constitucionais e frequentes injustiças.

Palavras-chave: Direito Penal Simbólico - Sistemas Penais Paralelos e Subterrâneos - Vingança Privada.

\section{INTRODUÇÃO}

O presente artigo visa estudar as características, consequências e o efeito simbólico do Direito Penal, buscando compreender fundamentalmente a influência que esse exerce na ampliação dos sistemas penais paralelos e subterrâneos que infectam a justiça brasileira.

Primeiramente, será abordado o Direito Penal Simbólico em si, verificando seus efeitos e consequências na sociedade de risco atual, em que a globalização e a influência das mídias sobre as pessoas são crescentes, o que tende a ampliar cada vez mais o efeito simbólico que o Direito Penal exerce, tornando-o mais forte e, consequentemente, mais problemático.

Ao longo do texto, serão analisadas as implicações que a exploração do referido valor simbólico podem causar, como o desvio da real função do Direito Penal, a má escolha dos bens jurídicos tutelados, a interferência na política criminal adotada e como tudo isso, consequentemente, deslegitima o Direito Penal aos olhos da população.

Será verificado ainda, que com a deslegitimação do Direito Penal, a população se sente desamparada por parte do Estado, não acreditando mais no poder deste de punir ou diminuir a criminalidade como um todo.

A perda de legitimidade e a consequente falta de confiabilidade enfrentada pelo Direito Penal faz insurgir nos indivíduos um sentimento de 
insegurança e desconfiança frente ao Estado. Como consequência disso, as pessoas se investem no lugar do Estado como executores das penas, buscando para si o jus puniendi, gerando, desta forma, os sistemas penais paralelos e subterrâneos que serão examinados ao final do estudo

\section{DIREITO PENAL SIMBÓlico, SEUS EFEITOS E CONSEQUÊNCIAS}

A comunidade brasileira atual é afligida pela constante incerteza e insegurança, a chamada "sociedade de risco" em que vivemos é marcada pelo perigo constante ao qual todos estão expostos. Não há mais segurança em que se confiar; toda prevenção parece não ser suficiente para evitar sinistros; todo o mundo globalizado é assolado pelo constante risco apresentado às pessoas, seja pelas atividades hoje desempenhadas configurarem muitas vezes riscos à integridade física, seja pela crescente poluição que afeta à saúde de todos, ou até mesmo pela constante e cada vez maior onda de crimes que marcam os presentes dias. Toledo e Assis comentam os traços marcantes desta sociedade atual:

A sociedade moderna então se tornou uma "sociedade de risco", na medida em que passou a vivenciar o perigo como uma normalidade. A violência foi a responsável por gerar uma sensação coletiva de insegurança, impulsionada pelos meios de comunicação, que, a todo o momento, transmitem mensagens aos telespectadores, fazendo com que estes sejam vítimas em potencial e retratando a sociedade como desestruturada. 3

Tal risco constante que é enfrentado por todos influencia de forma marcante o Direito como um todo; incontáveis leis são criadas e inúmeros institutos jurídicos são aperfeiçoados levando-se em conta as intempéries existentes. A título de exemplo, pode ser citado, no ramo do Direito

\footnotetext{
${ }^{3}$ TOLEDO, Kelvia De Oliveira; ASSIS, Claudio Abel Franco De. O simbolismo penal e a deslegitimação do poder punitivo na sociedade de risco: consequências e imprecisões. Revista de criminologias e políticas criminais, Minas Gerais, v. 1, n. 2, p. 238 - 266, jul./dez. 2015. Disponível em: <http://www.indexlaw.org/index.php/revistacpc/article/view/42>.Acesso em: 10 ago. 2017. P. 241
} 
Civil, a chamada "teoria da imprevisão", prevista no artigo 478 do Código Civil $^{4}$., que flexibiliza a força obrigatória dos contratos no caso de eventos imprevisíveis e extraordinários, mostrando deste modo, nitidamente, a consciência por parte do Direito dos riscos e incertezas existentes no mundo atual. Tal fenômeno não poderia se dar de maneira diferente no campo do Direito Penal, que é o maior legitimado a amparar a sociedade das mais graves ofensas e ameaças a seus direitos, mais ainda no que diz respeito aos direitos fundamentais tutelados constitucionalmente.

Quanto mais perigo a sociedade enfrenta, mais bens jurídicos tendem a serem ofendidos e, consequentemente, mais ampla se faz necessária a atuação do Direito Penal. Com o medo que as pessoas enfrentam, estas acabam por imaginar o Direito Penal como seu guardião, disposto a protegê-las de todos os tormentos da vida moderna. Assim sendo, as pessoas delegam ao Direito Penal tamanha confiança que faz com que esse se expanda e se torne detentor de um valor simbólico extremamente forte. Andrade comenta sobre alguns dos motivos da crescente expansão do Direito Penal:

Esse movimento de expansão do Direito Penal é favorecido, entre outros fatores, pela necessidade que o legislador possui em conseguir votos. Ao procurar os meios mais eficientes, vislumbrou no discurso incriminador um grande potencial para conseguir se eleger ou se reeleger. A população, alarmada pelo sentimento de insegurança, vê nos discursos incriminadores a solução fácil e rápida para o combate ao crime. ${ }^{5}$

Surge, deste modo, o que se convencionou chamar de Direito Penal Simbólico. Desde tempos remotos, o Direito Penal exerce um peso de símbolo sobre as pessoas. Tal simbolismo se traduz com a edição de novos tipos penais incriminadores, que servem primeiramente para proporcionar um sentimento de segurança na população, funcionando como um símbolo,

\footnotetext{
${ }^{4}$ Art. 478. Nos contratos de execução continuada ou diferida, se a prestação de uma das partes se tornar excessivamente onerosa, com extrema vantagem para a outra, em virtude de acontecimentos extraordinários e imprevisíveis, poderá o devedor pedir a resolução do contrato. Os efeitos da sentença que a decretar retroagirão à data da citação.

${ }^{5}$ ANDRADE, André Lozano. Os problemas do direito penal simbólico em face dos princípios da intervenção mínima e da lesividade. Revista Liberdades, n. 17, p. 99-117, set./dez. 2014. Disponível em: <http://www.revistaliberdades.org.br/site/outrasedicoes/outrasedicoesexibir.php?rcon_id=214>.Acesso em: 10 ago. 2017. P. 100
} 
e não como uma solução eficaz, como afirma Júnior, "O direito penal tem se tornado simbólico em razão de sua ineficiência quanto à finalidade precípua do Direito Penal. " ${ }^{6}$, surtindo deste modo somente o efeito de tranquilizar as pessoas e não efetivamente diminuir a criminalidade. Conforme explana Galdi:

O simbolismo do direito penal aparece com a edição das normas jurídicas penais exigidas pela sociedade do risco quando um crime a choca. As suas classes sociais altas se assustam quando o crime sai da esfera abstrata das suas classes sociais baixas, exigindo uma resposta estatal. O Estado responde agravando as penas dos crimes existentes e, consequentemente, ferindo o princípio da proporcionalidade penal. Na prática, a ineficácia do aumento dessas penas para inibir a criminalidade e para sanar a carência das medidas sociais redutoras da criminalidade é evidente. ${ }^{7}$

Tal símbolo, além de gerar nos indivíduos um sentimento de segurança, faz com que estes acreditem que quando o Estado cria tipos penais incriminadores e sanções para quem cometer delitos estaria proporcionando uma maior segurança real, pois acreditam que nestes casos quem cometer um delito será punido, afastado da sociedade e não mais voltará a delinquir. Também gera nas pessoas um sentimento de medo; desta forma os indivíduos não cometeriam mais crime algum em razão do temor de que as cominações prometidas pelo Direito Penal sejam realmente efetivadas.

O segundo efeito mencionado no parágrafo anterior diz respeito à prevenção geral negativa da pena, que supostamente inibe a prática de condutas delituosas dispondo simplesmente do valor simbólico do Direito Penal. Juarez Cirino dos Santos disserta, criticamente, sobre o assunto:

Prevenção geral negativa. A prevenção geral negativa da ameaça penal pode ter efeito desestimulante em

\footnotetext{
${ }^{6}$ JUNIOR, Aguinaldo Ferreira Do Nascimento. Direito penal simbólico: a ineficiência do sistema penal contemporâneo. Revista JurES, [S.L.], v. 8, n. 16, p. 112-122, 2016. Disponível em: <http://revistas.es.estacio.br/index.php/juresvitoria/article/view/572>.Acesso em: 10 ago. 2017. P. 113

${ }^{7}$ GALDI, Juliana Quintino Vieira. A Sociedade do Risco e o Direito Penal Simbólico. Revista Direito Mackenzie, [S.L], v. 8, n. 1, p. 39-50, 2014. Disponível em: <http://editorarevistas.mackenzie.br/index.php/rmd/article/view/7451>. Acesso em: 10 ago. 2017. P. 47
} 
crimes de reflexão (crimes econômicos, ecológicos, tributários etc.), característicos do Direito Penal simbólico, mas não teria efeito em crimes impulsivos (violência pessoal ou sexual, por exemplo), próprios da criminalidade comum estampada nos meios de comunicação de massa. Logo, a inibição de impulsos antissociais pela ameaça penal somente seria relevante no Direito Penal simbólico - um direito destituído de eficácia instrumental e instituído para legitimação retórica do poder punitivo do Estado, mediante criação/difusão de imagens ilusórias de eficiência repressiva na psicologia do povo -, mas é absolutamente irrelevante no Direito Penal instrumental, cujo objeto é delimitado pela criminalidade comum, área de incidência exclusiva da repressão penal seletiva. ${ }^{8}$

Há de se ressaltar também que este efeito simbólico exercido pelo Direito Penal, se bem explorado, pode ser muito válido, inclusive auxiliando tal ramo jurídico em suas funções. É um dos elementos que pode fazer com que tal esfera do Direito atue de forma mais eficaz, podendo ser apontado como um aspecto positivo quando funciona de forma a mostrar a força do Direito Penal e a proporcionar um sentimento de segurança às pessoas.

Toledo e Assis comentam a validade da utilização deste valor simbólico:

Sabe-se que o Direito Penal, pela forma de repressão às ilicitudes e pela característica marcante de ser ultima ratio, se reveste de um símbolo. O recurso ao simbolismo enquanto instituto mostra-se válido e legítimo, uma vez que reconhece a força do Direito Penal. ${ }^{9}$

Salim e Azevedo, por sua vez, dissertam sobre o aspecto positivo apontado pela doutrina com relação ao Direito Penal Simbólico:

Entretanto, apesar desse aspecto negativo da função simbólica do Direito penal, a doutrina aponta um aspecto "positivo", consistente na geração do sentimento de segurança e tranquilidade para a sociedade,

\footnotetext{
${ }^{8}$ SANTOS, Juarez Cirino Dos. Direito penal: parte geral. 6 ed. Curitiba: ICPC Cursos e Edições, 2014. P. 454

${ }^{9}$ TOLEDO, Kelvia De Oliveira; ASSIS, Claudio Abel Franco De. op. cit., nota 1, P. 244
} 
que em um primeiro momento acredita na eficácia da lei penal. ${ }^{10}$

Porém, pela crescente insegurança e medo da sociedade frente aos riscos modernos, esta acaba precisando de um símbolo cada vez mais forte, que lhe proporcione uma maior sensação de confiança e segurança, e iniba de forma mais adequada o cometimento de delitos.

Como consequência desta necessidade comunitária, o valor simbólico do Direito Penal está sendo constantemente mais explorado pela imprensa, que reproduz todas as espécies de riscos existentes, pois as pessoas se interessam pelos perigos que sofrem e, consequentemente, geram maior audiência para este tipo de atração; porém, isto aumenta a sensação de medo enfrentado pelas pessoas, que passam a cobrar do Estado maior atuação e segurança, e ele por sua vez promete investir no Direito Penal como solução para tais problemas. Sobre o assunto disserta Júnior:

A mídia constatou que o crime lhe proporciona maior audiência, consequentemente, mais lucro. A política, por sua vez, percebeu que a sociedade acometida pelo medo e insegurança em que vive está mais propensa a aceitar discursos punitivistas para resolver o problema da criminalidade. A partir dessa ideia, a sociedade é persuadida a acreditar que o aumento do número de leis penais e do rigor das penas, magicamente, reduzirá a criminalidade. ${ }^{11}$

Sendo assim, diante da ineficácia do Estado em solucionar os problemas sociais e econômicos, o que efetivamente diminuiria a criminalidade, busca-se iludir a sociedade através de sedutores discursos políticos e da mídia, com a criação de mais leis e o endurecimento das penas, utilizando o sistema penal repressivo como resolução dos problemas, o que o torna simbólico, haja vista que a criminalidade só tem aumentado. ${ }^{12}$

10 SALIM, Alexandre; AZEVEDO, Marcelo André De. Direito penal - parte geral. 7 ed. Salvador: JusPODVIM, 2017. P. 37

11 JUNIOR, Aguinaldo Ferreira Do Nascimento. op. cit., nota 4. P. 113

12 op. cit., nota 4. P. 114 
Além da imprensa, o mundo globalizado ajuda a fortalecer tal valor do Direito Penal. Crimes cometidos em qualquer parte do mundo são divulgados instantaneamente para todas as regiões do planeta; as pessoas sentem a insegurança uma das outras, nenhum local parece seguro quando se sabe que algo bárbaro acaba de ocorrer em algum local da Terra. $\mathrm{O}$ mundo globalizado une, de forma nunca vista, todos os indivíduos, conectando também todos seus medos e inseguranças.

Por todos estes motivos, a política se aproveita desta necessidade de segurança da população, prometendo para esta a fortificação do Direito Penal, objetivando a diminuição da criminalidade; promete aumentar a força das sanções e punir todos que as infringirem. Porém, deste modo, só acabam por fortalecer o símbolo que o Direito Penal representa como guardião dos justos e carrasco dos delinquentes, proporcionando uma falsa sensação de segurança que não se traduz em realidade. Pontuam claramente Salim e Azevedo sobre este aspecto:

Sempre que a sociedade clama por segurança pública, máxime nos tempos atuais de uma sociedade de risco, surge o legislador com sua pretensão de dar uma rápida resposta aos anseios sociais, e, com isso, muitas vezes criminaliza condutas sem qualquer fundamento criminológico e de política criminal, criando a ilusão de que resolverá o problema por meio da utilização da tutela penal. Com efeito, se a criação da lei penal não afeta a realidade, o Direito Penal acaba cumprindo apenas uma função simbólica. Daí a expressão Direito Penal simbólico. ${ }^{13}$

Com a excessiva exploração do Direito Penal Simbólico pela mídia e pelos políticos, as pessoas acabam dando um valor a esse ramo jurídico muito maior do que o que ele realmente representa, sendo desta maneira, deturpado, gerando efeitos e consequências não almejados e prejudiciais à justiça.

Andrade disserta, claramente, sobre o assunto:

Entre os fatores que mais dão eco à vontade da população em endurecer as leis, ou melhor, que direcionam a vontade da população em endurecer as leis, estão os

${ }^{13}$ SALIM, Alexandre; AZEVEDO, Marcelo André De. op. cit., nota 8. P. 36 
meios de comunicação e os políticos, visto que é a própria mídia que - através de reiteradas inserções de casos de violência - aumenta o sentimento de insegurança da sociedade. ${ }^{14}$

Por outro lado, políticos utilizam-se do medo da população para angariar votos. São construídas plataformas inteiras com base no incremento do Direito Penal. Políticos que não seguem essas plataformas de endurecimento da pena e criminalização de tudo, têm a imagem de demasiado libertários e perdem credibilidade, uma vez que são vistos como garantidores da impunidade. Lutar contra a criminalização de banalidades e por penas humanas ou proporcionais chega a ser um verdadeiro suicídio político. ${ }^{15}$

No decorrer do presente artigo, será visto como esta exploração desmedida do valor simbólico do Direito Penal acaba por desiludir a população quanto ao real poder de tal setor do Direito e, ao invés de favorecer a diminuição da criminalidade, a torna mais acentuada, auxiliando, inclusive, na formação de sistemas penais não amparados constitucionalmente.

\subsection{A DETURPAÇÃO DA REAL FUNÇÃO DO DIREITO PENAL}

Como apontado anteriormente, o valor simbólico do Direito Penal vem sendo cada vez mais explorado e mal utilizado pelo Poder Público, além de ser usurpado pela imprensa e ampliado pela globalização. Por esses e outros motivos, o Direito Penal Simbólico gera consequências e efeitos não almejados, e que não contribuem, ou até mesmo atrapalham, a efetivação da verdadeira função do Direito Penal.

Segundo Flávio Augusto Monteiro de Barros, o Direito Penal possui duas funções básicas: "proteção dos bens jurídicos e manutenção de paz social (...) Bens jurídicos são os valores ou interesses do indivíduo ou

\footnotetext{
${ }^{14}$ ANDRADE, André Lozano. op. cit., nota 3. P. 110

15 op. cit., nota 3. P. 111
} 
da coletividade, reconhecidos pelo direito. Paz social é a ordem que deve reinar na vida comunitária."16

O mal-uso do Direito Penal Simbólico vai corromper as funções primordiais do Direito Penal. Com relação à primeira função anteriormente citada, através do uso exacerbado do valor simbólico do Direito Penal, os bens jurídicos tutelados passam a ser corrompidos. Na dicção de Nucci: "Há bens tutelados pelo Direito, eleitos pelo ordenamento jurídico como indispensáveis à vida em sociedade, merecendo proteção e cuidado. A partir dessa escolha, o bem se transforma em bem jurídico." ${ }^{17}$ Dentre os bens jurídicos tutelados, somente os mais importantes para a vida em sociedade merecem a proteção do Direito Penal.

Com a insegurança que a exploração do Direito Penal simbólico causa nas pessoas, estas cobram do Estado que este tutele de forma mais incisiva cada vez mais bens jurídicos. Com isto, são eleitos como bens jurídicos pelo Direito, valores que não são necessariamente indispensáveis à vida em sociedade, ou até mesmo não são constitucionalmente relevantes. Consequentemente, a função de protetor dos bens jurídicos do Direito Penal é desvirtuada, pois os próprios bens jurídicos protegidos por tal ramo do Direito o são.

O referido desvio na escolha de bens jurídicos a serem tutelados pelo Direito penal, além de corromper a função de tal ramo jurídico, viola o caráter de ultima ratio do Direito Penal, conforme expõe Salim e Azevedo:

O Direito Penal é uma das formas de controle social, assim como o Direito Civil e o Direito Administrativo. Entretanto, a sanção penal é considerada a mais grave das sanções, justamente por permitir a privação da própria liberdade. Por isso, o Direito Penal deve atuar de forma subsidiária (Direito Penal de ultima ratio), isto é, somente quando insuficiente as outras formas de controle social.

Assim, o Direito Penal deve ser um meio necessário de proteção do bem jurídico. A tutela penal deixa de

${ }^{16}$ BARROS, Flávio Augusto Monteiro de. Direito penal, parte geral: v. 1. 4. ed. São Paulo: Saraiva, 2004. P. 3

${ }^{17}$ NUCCI, Guilherme de Souza. Manual de Direito Penal: parte geral: parte especial. 9. Ed. São Paulo: Editora Revista dos Tribunais, 2013. P. 74 
ser necessária quando existir, de forma eficaz, outros meios de controle social (formais ou informais) menos lesivos aos direitos individuais. ${ }^{18}$

Com relação ao objetivo de efetivação da paz social, o uso exagerado do valor simbólico do Direito Penal vai contra esta função, pois com a exploração do medo e da insegurança da população ela não viverá mais em absoluta paz; quando o símbolo de protetor que reveste o Direito Penal é corrompido, a população perde a fé nele e acaba por sentir um medo ainda maior. De forma alguma, o Direito Penal Simbólico exageradamente explorado irá contribuir para a diminuição da criminalidade; pelo contrário, como será visto ao longo do presente texto, a tendência é que se faça por aumentar a incidência de ofensa a bens jurídicos constitucionais.

A elaboração de leis incriminadoras, quando não bem efetivadas, não contribui para a paz social; ao oposto, acaba por gerar medo nas pessoas em viver livremente, e estas perdem, inclusive, a confiança no Estado, só aumentando deste modo o sentimento de insegurança e, consequentemente, proporcionando cada vez mais conflitos sociais. Conforme explicam Toledo e Assis:

Busca-se editar normas de pouca ou nenhuma eficiência que tem o condão somente de dar uma resposta ligeira à população alarmada com as notícias sobre a criminalidade. Tais leis são elaboradas sem qualquer proteção efetiva na norma penal incriminadora, violando, dessa forma, o Direito Penal mínimo e o princípio da lesividade, uma vez que certas condutas são punidas de modo desnecessário, antecipando a punição e criminalizando comportamentos que não geram qualquer perigo real ou efetivo. ${ }^{19}$

Deste modo, pode ser percebido como o uso exagerado do símbolo representado pelo Direito Penal pode desvirtuar sua real função, modificando a função do Direito Penal para nada mais do que angariar votos para políticos ou para aumentar o interesse da população por mídias que exploram a criminalidade e insegurança da sociedade de risco.

18 SALIM, Alexandre; AZEVEDO, Marcelo André De. Direito penal - parte geral. 7 ed. Salvador: JusPODVIM, 2017. P. 52

${ }^{19}$ TOLEDO, Kelvia De Oliveira; ASSIS, Claudio Abel Franco De. op. cit., nota 1. P. 245 
O Direito Penal deve ser utilizado para a proteção tão somente dos bens mais importantes para que seja mantida a paz da sociedade; corromper seu caráter de ultima ratio e o princípio da intervenção mínima, usando-o somente como símbolo, acabará sem dúvida por desviá-lo de sua real função, conforme explica Sanches:

(...) há casos em que somente o Direito Penal é capaz de evitar a ocorrência de atos ilícitos ou de puni-los à altura da lesão ou do perigo a que submeteram determinado bem jurídico, dotado de relevância para a manutenção da convivência social pacífica. É a partir daí que se verifica a importância do princípio da intervenção mínima, segundo o qual o Direito Penal só deve ser aplicado quando estritamente necessário (ultima ratio), mantendo-se subsidiário. ${ }^{20}$

A perda da real função do Direito Penal produz outros diversos efeitos não almejados que serão tratados adiante. Deste modo, deve se ter cautela em não distorcer o Direito Penal para que este não represente nada além de um símbolo sem eficácia alguma; deve-se velar para que este seja focado em suas funções primordiais citadas anteriormente, para que, deste modo, tal ramo do Direito consiga auxiliar na redução da criminalidade.

\subsection{INFLUÊNCIA SOBRE A POLÍTICA CRIMINAL}

Além de distorcer as verdadeiras funções do Direito Penal, o uso extrapolado do valor simbólico de tal ramo jurídico pode trazer inúmeras outras consequências danosas à Justiça brasileira. Um desses principais danos diz respeito ao desvio da política criminal.

Com o uso exacerbado do símbolo do Direito Penal, cresce o temor da população, que por sua vez pede uma atitude mais incisiva do Poder Público. Sendo assim, cada vez mais o legislador cria figuras incriminadoras para buscar dar uma sensação ficta de segurança à população, modificando deste modo os bens jurídicos tutelados, gerando uma expansão do ramo Penal, conforme analisado no tópico anterior.

${ }^{20}$ CUNHA, Rogério Sanches. Manual de direito penal: parte geral. 5. ed. Salvador: JusPODIVM, 2017. P. 76 
Como consequência desta descaracterização dos bens jurídicos, a própria política criminal é influenciada, sofrendo diretamente os efeitos do uso indevido do Direito Penal Simbólico.

Conforme explica Nucci, política criminal pode ser entendida da seguinte forma:

(...) parece-nos que política criminal é uma maneira de raciocinar e estudar o Direito Penal, fazendo-o de modo crítico, voltado ao direito posto, expondo seus defeitos, sugerindo reformas e aperfeiçoamentos, bem como com vistas à criação de novos institutos jurídicos que possam satisfazer as finalidades primordiais de controle social desse ramo do ordenamento. ${ }^{21}$

Ao se dar ênfase somente ao poder simbólico do Direito Penal e não à sua real função, será, consequentemente, deturpada também a elaboração da política criminal, tornando esta ineficiente para alcançar seu objetivo. Ao invés de se aperfeiçoar o Direito Penal, ela o prejudicará, tornando-o menos eficaz em seu fim, aumentando desta forma o descontrole social e o cometimento de delitos.

Todo este panorama se desenvolve por causa do uso e abuso por parte dos políticos do Direito Penal Simbólico como estratégia de campanha, explorando a insegurança da população para angariar votos e manterse no poder, sem se preocupar com a realidade do problema criminal. Como ensina Andrade:

Por outro lado, políticos utilizam-se do medo da população para angariar votos. São construídas plataformas inteiras com base no incremento do Direito Penal. Políticos que não seguem essas plataformas de endurecimento da pena e criminalização de tudo, têm a imagem de demasiado libertários e perdem credibilidade, uma vez que são vistos como garantidores da impunidade. Lutar contra a criminalização de banalidades e por penas humanas ou proporcionais chega a ser um verdadeiro suicídio político. ${ }^{22}$

\footnotetext{
${ }^{21}$ NUCCI, Guilherme de Souza. op. cit., nota 15. P. 72

${ }^{22}$ ANDRADE, André Lozano. op. cit., nota 3. P. 111
} 
Ao prometerem uma modificação na política criminal, com o único objetivo de iludir a população para angariar votos, aquela passará a não mais servir como aperfeiçoadora do Direito Penal; pelo contrário, ela servirá unicamente para atender interesses políticos, que se traduzem na exploração da insegurança da população e no uso desmedido do Direito Penal como símbolo do combate à criminalidade.

Portanto, para se diminuir a ocorrência de delitos, criar somente leis não é o suficiente; o uso extrapolado desta forma de combate ao crime pode gerar grandes infortúnios, como explica Francisco de Assis Toledo:

O crime é um fenômeno social complexo que não se deixa vencer totalmente por armas exclusivamente jurídico-penais. Em grave equívoco incorrem, frequentemente, a opinião pública, os responsáveis pela Administração e o próprio legislador, quando supõem que, com a edição de novas leis penais, mais abrangentes ou mais severas, será possível resolver-se o problema da criminalidade crescente. Essa concepção de direito penal é falsa porque o toma como uma espécie de panaceia que logo se revela inútil diante do incremento desconcertante das cifras da estatística criminal, apesar do delírio legiferante de nossos dias.

Não percebem os que pretendem combater o crime com a só edição de leis que desconsideram o fenômeno criminal como efeito de muitas causas e penetram em um círculo vicioso invencível, no qual a própria lei penal passa, frequentemente, a operar ou como importante fator criminógeno, ou como intolerável meio de opressão. ${ }^{23}$

Assim fica evidenciado mais um ponto negativo do uso indevido do Direito Penal Simbólico como meio de acalmar a insegurança da sociedade de risco globalizada. Quando a população percebe que foi usada, e que o Direito Penal não passou de um símbolo sem efeito prático, ela perde a confiança no Poder Público, o que acaba por gerar consequências desastrosas, que serão analisadas ao final deste artigo.

\footnotetext{
${ }^{23}$ TOLEDO, Francisco de Assis. Princípios básicos de direito penal. 5 ed. São Paulo: Saraiva, 1994. p. 5
} 


\subsection{A PERDA DE LEGITIMIDADE DO DIREITO PENAL}

O uso desmedido do Direito Penal Simbólico com o intuito de iludir a população da eficácia do Direito Penal no combate ao crime gera nela uma falsa sensação de segurança, pois faz com que acredite na falsa ideia de que o uso de tal ramo do Direito irá resolver o problema do alto índice de criminalidade e, consequentemente, gerar uma maior segurança.

Porém, como a real função do Direito Penal não está diretamente ligada à redução dos índices de crimes, e nem mesmo é o instrumento capaz de tornar isto realidade, o seu fortalecimento não trará este resultado que foi prometido através de discursos políticos à população. Seguindo esta linha, ensina Andrade:

Chega-se à seguinte conclusão: longe de dar solução aos conflitos sociais gerados pelo crime, o direito penal simbólico visa esconder os problemas e postergar a solução de problemas, gerando o descrédito das instituições e do Estado, na medida em que fica claro que não são capazes de lidar com a criminalidade. ${ }^{24}$

Quando a sociedade percebe que a incidência de delitos nem sequer diminuiu com a criação e endurecimento de leis, e que os riscos persistem mesmo com a maior rigidez do Direito Penal, esta começa a vislumbrar que o que realmente se fortaleceu foi somente o valor simbólico de tal Direito, que sua eficácia prática continua a mesma ou até mesmo restou prejudicada.

O crime continua nas ruas, e quem prometeu que o Direito Penal seria a única ou a melhor solução não falou de acordo com a realidade. Sobre esse desvio de foco e falsa promessa de segurança gerada pelo Direito Penal Simbólico, disserta Andrade:

Acrescente-se a isso que Direito Penal simbólico acaba por dar uma falsa sensação de segurança, quando na verdade o que há é maior insegurança, visto que o sistema penal é obrigado a desviar de seu foco principal, destinado todo aparato do sistema penal a coibir condutas que poderiam muito bem ser evitadas utilizando-se outros meios e outros ramos do

\footnotetext{
${ }^{24}$ ANDRADE, André Lozano. op. cit., nota 3. P. 112
} 
Direito, o que deixaria as instituições destinadas à aplicação do Direito Penal livres para atuar apenas onde fosse estritamente necessário. ${ }^{25}$

Deste modo as pessoas compreendem que seu medo foi usado unicamente com fins políticos, perdendo totalmente a confiança que possuíam no Poder Público como capaz de diminuir a ocorrência de delitos. Se isto não bastasse, como as criações de leis penais não foram capazes de resolver os problemas aos quais foram designadas, a população perde a confiança no Direito Penal como um todo, inclusive chegando ao ponto de deslegitimá-lo em sua suposta função de combater o crime.

Vale ressaltar que a verdadeira função do Direito Penal foi deturpada pela mídia e pelos discursos políticos; foi passada à população uma imagem de tal ramo do Direito que não corresponde a seu real objetivo. As leis penais, mesmo que cumpridas, parecem ineficazes aos olhos da população, pois esta quer somente a punição dos criminosos e a sua própria proteção.

Muitas das medidas que buscam a ressocialização dos criminosos, como, por exemplo, a suspensão do processo penal ou aplicação de penas restritivas de Direito, fazem com que o povo entenda que foi dado um salvo conduto para um criminoso; não consegue perceber que o que realmente ocorreu foi a pura e simples aplicação da lei penal. Como explica Galdi:

A sensação da insegurança jurídica é a do descumprimento aparente do direito penal. O adjetivo "aparente" foi empregado na frase anterior propositalmente. $\mathrm{O}$ direito penal é cumprido efetivamente. Um criminoso condenado por um crime cuja pena mínima for igual/inferior a um ano pode ter a sua ação judicial penal suspensa por dois a quatro anos, desde que seus requisitos sejam cumpridos (art. 89, caput, da Lei Federal n. 9.099/1995). Assim, embora o criminoso retromencionado esteja livre, o direito penal foi cumprido efetivamente. Mas, para a sociedade do risco, a sua liberdade significa a sua impunidade, 
independentemente do que o direito penal preveja. Essa desarmonia o afeta, trazendo lhe consequências graves. ${ }^{26}$

A primeira impressão de gerar segurança que o Direito Penal Simbólico causa na população se torna efêmera quando o próprio Direito Penal é deturpado em suas reais funções ao serem criados bens jurídicos ilegítimos de tutela penal.

Como o valor simbólico faz com que as pessoas acreditem estarem protegidas pelo Direito Penal e que os delinquentes serão punidos, quando isto não se traduz na realidade a população, percebendo que foi iludida, não mais acredita no valor de símbolo que o Direito Penal antes possuía; ninguém mais passa a confiar em sua eficácia, destruindo qualquer meio de prevenção negativa que ele antes exercia. Andrade disserta sobre a perda de legitimidade do Direito Penal:

Quando se criminaliza condutas desnecessariamente o sistema penal perde legitimidade, pois, por um lado não consegue combater todas as condutas criminalizadas e, por outro, a sociedade, em longo prazo, notará que o sistema é falho e seus agentes incapazes de garantir a segurança e lidar com a criminalidade, $o$ que gerará um efeito em cadeia. ${ }^{27}$

Como consequência, a criminalidade aumenta, e a população novamente se vê com uma maior insegurança ante aos riscos que enfrenta, e agora não mais possui símbolo algum no qual se apoiar, se sente desamparada frente aos inúmeros perigos existentes, fazendo com que busque agir por conta própria para buscar sobreviver.

Na medida em que esta deslegitimação e falta de confiança popular no Direito Penal cresce, este perde todo valor simbólico que um dia possuiu, não mais servindo para dar segurança de sua funcionalidade, embora continue realizando sua real função; nem mais coage os delinquentes a não praticar crimes, pois estes pensam que o Direito Penal era só um símbolo pregado pela mídia e pelos políticos que não é revestido de efeito prático algum, gerando deste modo um círculo vicioso, conforme expõe Andrade:

${ }^{26}$ GALDI, Juliana Quintino Vieira. op. cit., nota 5. P. 45

${ }^{27}$ ANDRADE, André Lozano. op. cit., nota 3. P. 101/102 
Com isso as próprias instituições ficam desacreditadas, sendo insuficientes para resolver as questões criminais, o que gera um círculo vicioso, pois o clamor popular e midiático exigirá mais criminalizações para resolver o problema da violência, quando na verdade o problema é estrutural. ${ }^{28}$

Com isto, a população busca para si a legitimidade de impedir que o crime ocorra, pois o Direito Penal falhou neste aspecto. Mesmo que este nunca tenha sido seu real objetivo, foi o que a mídia e os discursos políticos pregaram que era, e agora que ele se mostrou ineficaz para este fim as pessoas acreditam que não podem mais deixar somente na mão do Estado o poder de punir e evitar crimes, buscando, deste modo, aplicar o jus puniendi por conta própria com a esperança de que a criminalidade latente seja reduzida, ou ao menos, vingada.

\section{SISTEMAS PENAIS PARALELOS E SUBTERRÂNEOS}

Dentre todas as consequências causadas pelo uso desmedido do Direito Penal Simbólico, talvez a mais preocupante diga respeito à perda da legitimidade do Direito Penal aos olhos de uma parcela da população. Conforme afirmam Toledo e Assis, "o Direito Penal não pode ser transformado em um sistema de satisfação de expectativas e anseios da sociedade, sob pena de se transformar em um instituto desacreditado e ineficaz quanto à sua proposta original" ${ }^{29}$. Isto porque este efeito gera inúmeras outras implicações, como é o caso do surgimento dos sistemas penais paralelos e subterrâneos, que serão analisados a seguir.

Quando as pessoas perdem a confiança de que o Direito Penal possa punir e combater a criminalidade, e não conseguem perceber outro meio estatal para tal fim, elas buscam a legitimidade para si. Tentam dessa forma se apoderar de uma parcela do jus puniendi estatal, pois pensam que o Poder Público não fez bom uso deste e não merece mais ter sua exclusividade.

Assim nascem o que o professor Zaffaroni chamou de sistemas penais paralelos, quando o Estado negligencia uma enorme parte de seu

\footnotetext{
${ }^{28}$ ANDRADE, André Lozano. op. cit., nota 3. P. 109

${ }^{29}$ TOLEDO, Kelvia De Oliveira; ASSIS, Claudio Abel Franco De. op. cit., nota 1. p. 246.
} 
poder punitivo e esse é tomado pelas pessoas; e os sistemas penais subterrâneos, quando as agências executivas exercem poder punitivo à margem do Direito ou fora da legalidade ${ }^{30}$. Salim e Azevedo, citando o referido autor explicam que:

$\mathrm{Na}$ verdade, se referem aos sistemas penais paralelos e subterrâneos. Segundo Zaffaroni, sistema penal é o conjunto das agências que operam a criminalização primária e a criminalização secundária ou que convergem na sua produção. Denomina-se criminalização o processo de seleção de um número reduzido de pessoas realizado pelo Estado (detentor do Poder), as quais serão submetidas à punição. A criminalização primária é a elaboração das leis penais, ao passo que o programa deve ser cumprido pelas agências de criminalização secundária (Polícia, Ministério Público, Judiciário e agentes penitenciários). ${ }^{31}$

Como a população perdeu o crédito na funcionalização dos sistemas penais instituídos por lei e efetivados pelo Estado, ela passa a "criar" seus próprios sistemas penais, à margem de qualquer legalidade, executando julgamentos e punições sem qualquer base legal ou constitucional.

Conforme já mencionado, como consequência, quando os sistemas penais elaborados e aplicados pelo Estado não dão o respaldo esperado pela população, ela age por conta própria. Quando os particulares atuam dentro de suas relações buscando suprir esta ineficiência estatal e buscando aplicar o jus puniendi por contra própria, configura-se o sistema penal paralelo, conforme dissertam Salim e Azevedo.

Porém, como o sistema penal formal do Estado não exerce grande parte do poder punitivo, outras agências acabam se apropriando desse espaço e passam a exercer o poder punitivo paralelamente ao estado (sistemas penais paralelos). Ex.: médico aprisionando doentes mentais; institucionalização pelas autoridades assistenciais dos moradores de rua; famílias

${ }^{30}$ ZAFFARONI, Eugenio Raul; ALAGIA, Alejandro; SLOKAR, Alejandro. Derecho Penal - Parte General. $2^{a}$ Edição. Buenos Aires: Ediar Sociedad Anónima Editora, 2002. p. 2526.

${ }^{31}$ SALIM, Alexandre; AZEVEDO, Marcelo André De. op. cit., p. 37, nota 16. 
abandonando pessoas idosas em estabelecimentos particulares; autoridades administrativas e as corporações ao impor sanções que implicam desemprego, que pode ser mais grave que uma sanção penal. ${ }^{32}$

Quando dentro dos próprios sistemas penais estatais, os agentes do Estado tentam atuar fora da legalidade, pois pensam que tais sistemas do modo que são executados não funcionam: nascem, então, os sistemas penais subterrâneos. Conforme ensinam Salim e Azevedo:

No escólio do citado autor, "todas as agências executivas exercem algum poder punitivo à margem de qualquer legalidade ou com marcos legais muito questionáveis, mas sempre fora do poder jurídico", o que acarreta um abuso de poder. Chama-se esse âmbito de atuação ilícita de sistema penal subterrâneo. Ex.: institucionalização de pena de morte (execução sem processo), desaparecimentos, torturas, extradições mediante sequestro, grupos especiais de inteligência italianos, norte-americanos e espanhóis que atuam fora da lei. ${ }^{33}$

É evidente que o mau-uso do valor simbólico do Direito Penal e sua consequente deslegitimação são fatores essenciais que contribuem para o aparecimento de tais sistemas penais, pois, como dissertado anteriormente, quando se faz com que as pessoas pensem que o Direito Penal tem como fim punir e reprimir a criminalidade e isto não ocorre, a população perde a confiança em tal ramo do Direito e passa a não mais acreditar nele, buscando assim agir por conta própria. Na visão de Zaffaroni, esta deslegitimação do sistema penal estatal é consequência direta na propagação dos sistemas penais que atuam fora da legalidade. Toledo e Assis com base nos ensinamentos do referido autor dissertam que:

Assim sendo, para Zaffaroni (1991) a coerência interna do discurso jurídico-penal e o seu valor de verdade quanto à operatividade social deveriam colaborar para que o sistema se legitimasse por si mesmo, contudo não há racionalidade, pois não há coerência

\footnotetext{
${ }^{32}$ SALIM, Alexandre; AZEVEDO, Marcelo André De. op. cit., p. 37, nota 16. 33 op. cit., p. 38 , nota 16 .
} 
nem mesmo internamente ao próprio sistema penal. Essa negação da própria coerência interna do discursojurídico-penal salta à vista com argumentos positivistas como "assim diz a lei", "é assim porque o legislador quer", e esses imbróglios são constantemente usados na América Latina e que demonstram mesmo a falha das tentativas de racionalização e de legitimação do exercício de poder do sistema penal (ZAFFARONI, 1991).

Um sintoma, na visão do mestre argentino, da deslegitimação sistêmica do Direito Penal é que o sistema penal não atua conforme a legalidade, sendo esta, em certo sentido, a operacionalidade real do sistema penal. A questão mesmo é que os órgãos que convergem do sistema penal não exercem seus poderes de acordo com a programação da lei oriunda do discurso jurídico-penal. ${ }^{34}$

Deste modo, as pessoas buscam assumir a legitimidade supostamente perdida pelo Direito Penal; à medida que isto ocorre, cada indivíduo passa a se presumir detentor do jus puniendi que ele considera não mais pertencer ao Estado, obedecendo somente à sua moral para aplicação das punições que julga ser necessárias.

Como ninguém mais se sente seguro ante a aparente ineficácia do Poder Público, inclusive promovida pela mesma mídia que abusou de forma extravagante do valor do Direito Penal como combatente da criminalidade, cada indivíduo age de forma a tentar evitar a ocorrência de crimes, e quando estes ocorrem passam a buscar punir no lugar do Estado. Deste modo tornando cada vez mais frequente os sistemas penais paralelos e subterrâneos supracitados.

São rotineiros os linchamentos ocorridos quando um suspeito de algum crime é apreendido pela população. Esta não quer mais esperar a resposta estatal, pois tal resposta não condiz com o anseio popular de punição causado pelo grande medo enfrentado pela sociedade de risco. As pessoas agem por conta própria e garantem que a sociedade será vingada e o mal causado retribuído imediatamente; não querem ter mais esta incerteza a enfrentar. Assim se traduzem os sistemas penais paralelos. Grande

34 TOLEDO, Kelvia De Oliveira; ASSIS, Claudio Abel Franco De. op. cit., nota 1. p. 247248. 
fator para isto ocorrer, como visto, é a perda da legitimidade do Direito Penal, como disserta Andrade:

Com a incredulidade da sociedade nas instâncias penais abre-se uma larga avenida pera que medidas autoritárias e ilegais sejam legitimadas pela população e pelos políticos em geral. Execuções são justificadas em nome da paz social, chegando, o governador do Estado de São Paulo, a dizer que numa atuação policial que culminou com a morte de nove pessoas, sendo que entre elas havia quem sequer tivesse antecedentes criminais, estariam justificadas. ${ }^{35}$

Além destes casos, ocorre também de os próprios agentes do Estado atuarem fora do sistema penal legal. Quando, por exemplo, a polícia tortura um averiguado para conseguir uma prova, nem mesmo os agentes do Estado confiam que o Poder Público irá dar uma resposta satisfatória em relação a um crime cometido e buscam, deste modo, agir por conta própria longe de se submeter a qualquer legalidade. Deste modo se traduz o sistema penal subterrâneo, que pode ser apontado como consequência do uso desmedido do valor simbólico do Direito Penal, conforme ensina Andrade:

Esse sentimento de que execuções realizadas pela polícia são justificadas se dá, entre outros fatores, pelo fato de se preferir fingir que se combate o crime por meio da simbologia do que efetivamente mirar suas causas e buscar soluções que resolvam ou pelo menos amenizem a questão da criminalidade e tantos outros problemas sociais. ${ }^{36}$

Tais sistemas podem até aparentar proporcionar uma resposta imediata de punição à população, porém, é evidente que tais punições sumárias podem trazer em seu encalço grandes injustiças, além de ser, visivelmente, uma afronta à Constituição.

\footnotetext{
${ }^{35}$ ANDRADE, André Lozano. op. cit., p. 113-114, nota 3.

36 op. cit., p. 114, nota 3 .
} 


\subsection{A VOLTA DA VINGANÇA PRIVADA}

Com as pessoas assumindo para si o jus puniendi, na prática, o que ocorre é que os indivíduos estão buscando fazer "justiça" com as próprias mãos. Ninguém mais respeita a autoridade que o Estado representava através do Direito Penal; as leis, por não darem o respaldo que a população esperava não são mais acatadas, todo julgamento e execução da pena passam desta forma para as mãos privadas.

Porém, não há que se falar que tal fenômeno se traduza em justiça, não por simplesmente atender o clamor popular. Executar de forma célere com base no calor do momento não significa que o julgamento proveniente será justo, muito pelo contrário, execuções sumárias tendem a ser as mais injustas. $\mathrm{O}$ que ocorre na verdade é a volta da vingança privada, efetivada agora através dos sistemas penais paralelos e subterrâneos.

A vingança privada pode ser traduzida na atribuição à própria pessoa que sofreu o mal ou do próprio corpo social do poder de punir; o que se configura é a própria vingança e não a justiça, não se objetiva reparar o dano causado ou ressocializar o delinquente, mas simplesmente devolver a ele o mal que ele causou à coletividade. Nas palavras de E. Magalhães Noronha:

Como se observa nas espécies inferiores, a reação à agressão devia ser a regra. A princípio, a reação do indivíduo contra o indivíduo, depois, não só dele como de seu grupo, para mais tarde, já o conglomerado social colocar-se ao lado destes. É quando então se pode falar propriamente em vingança privada, pois até aí, a reação era puramente pessoal, sem intervenção ou auxílio de estranhos. ${ }^{37}$ (p. 24)

Agora, o homem age através dos sistemas penais paralelos e subterrâneos, pois o que ocorre é um clamou por vingança para retribuir o mal sofrido pela sociedade. Não se pode acreditar que o que deriva de tais sistemas é justiça, não se pode falar em justiça quando garantias constitucionais são violadas, quando a pena é aplicada sem um devido processo legal.

Um efeito maléfico para a função do Direito Penal diz respeito ao descontrole social. A vingança privada faz com que o conflito entre as

${ }^{37}$ NORONHA, E. Magalhães. Direito Penal: $1^{\circ}$ Volume. 2. Ed. São Paulo: Saraiva, 1963. p. 24 . 
pessoas aumente demasiadamente, pois estas assumem o papel de juízes, não existe um agente imparcial para resolver os conflitos, cada indivíduo tenta impor a sua vontade como a correta e efetivá-la. Nesse sentido disserta E. Magalhães Noronha:

Entretanto, o revide não guarda proporção com a ofensa, sucedendo-se por isso lutas acirradas entre grupos e famílias, que assim, se iam debilitando, enfraquecendo e extinguindo. Surge, então, como primeira conquista no terreno repressivo o talião. Por ele, delimita-se o castigo; a vingança não será mais arbitrária e desproporcionada. ${ }^{38}$

Pode-se concluir que estes sistemas fazem com que o Direito volte a ter características da era da vingança privada. Jogando fora, deste modo, importantíssimas garantias conquistadas pela humanidade e traduzidas no texto constitucional.

\subsection{MALEFÍCIOS CAUSADOS AO DIREITO BRASILEIRO}

Todas estas mazelas causadas pelo uso desmedido do Direito Penal Simbólico são intensificadas pelos sistemas penais paralelos e subterrâneos. Tais efeitos representam inúmeros danos à justiça brasileira.

É marcante a afronta de tais sistemas ao ordenamento jurídico brasileiro. Quando as pessoas se colocam no lugar do Estado para punir os suspeitos de cometeram delitos, agindo deste modo por conta própria e somente levando em conta o que sua moral considera justo, sem levar em consideração as garantias e direitos inerentes à pessoa humana, é inevitável que direitos básicos e garantias constitucionais do acusado sejam desrespeitados.

Dentre os mais nitidamente ofendidos se encontra a garantia ao devido processo legal previsto no art. $5^{\circ}$, incisos LIV e LV, da Constituição Federal ${ }^{39}$; além de inúmeros outros princípios e garantias constitucionais,

\footnotetext{
${ }^{38}$ NORONHA, E. Magalhães. op. cit., p. 25, nota 33.

${ }^{39}$ Ninguém será privado da liberdade ou de seus bens sem o devido processo legal; aos litigantes, em processo judicial ou administrativo, e aos acusados em geral são assegurados o contraditório e ampla defesa, com os meios e recursos a ela inerentes;
} 
como, por exemplo, o princípio do contraditório, da ampla defesa, inclusive o princípio da dignidade da pessoa humana e o princípio da humanidade que devem ser observados na aplicação de penas.

Esses fatores causam uma imensa insegurança jurídica: qualquer um que for suspeito ou acusado de ter cometido um delito, sendo possível que muitas vezes se tratem de pessoas inocentes, não terá uma investigação e consequente processo com suas garantias respeitadas; o risco de uma execução sumária e injusta ocorrer se mostra demasiadamente provável. Deste modo, como não existe nenhuma cautela a ser observada, qualquer pessoa suspeita de ter cometido um crime pode ser vítima dos sistemas penais paralelos e subterrâneos.

Outra grande consequência diz respeito à substituição da legitimidade que antes pertencia ao Estado e que agora passa para os sistemas paralelos e subterrâneos, esses visando somente à punição, seja ela qual for; não é comum a esses sistemas o objetivo de ressocializar os suspeitos ou aplicar uma punição correspondente ao suposto delito praticado. $\mathrm{O}$ fim almejado por esses sistemas penais, na maioria dos casos, é unicamente ver a sociedade vingada e o suspeito exemplarmente punido. Nada disso colabora para a Justiça brasileira, conforme disserta Andrade:

Não só os problemas não são resolvidos como surgem outros novos problemas. O cidadão, acreditando que nunca será alvo da investida do poder ilícito de agentes do Estado contra si, aplaude qualquer medida que redunde em mais punição e efetividade contra os "inimigos da sociedade". ${ }^{40}$

Os riscos de não se aplicar o sistema penal estatal, amparado por garantias e direitos constitucionais se concretiza rotineiramente na realidade. Como exemplo de barbárie causada pele execução do sistema penal paralelo, em que populares buscam assumir o jus puniendi estatal e fazer justiça com as próprias mãos, pode ser citado o caso emblemático no qual uma mulher foi morta espancada, pelo motivo de ter sido alvo de uma falsa acusação que partiu de uma página em uma rede social na qual se afirmava que ela sequestrava crianças para utilizá-las em rituais de magia negra ${ }^{41}$. Este é somente um caso entre os inúmeros que ocorrem quando as pessoas

\footnotetext{
${ }^{40}$ ANDRADE, André Lozano. op. cit., p. 114, nota 3.

41 http://g1.globo.com/sp/santos-regiao/noticia/2014/05/mulher-espancada-apos-boatosem-rede-social-morre-em-guaruja-sp.html
} 
buscam punir e vingar a sociedade de qualquer forma; sem garantias de que a verdade seja alcançada, a injustiça muitas vezes prevalece.

Igualmente ocorre quando se utiliza de sistemas penais subterrâneos para combater o crime. Apesar desses sistemas se desenvolverem muitas vezes dentro de órgãos estatais, do mesmo modo que ocorre nos paralelos, eles não respeitam as garantias previstas na Constituição a todo indivíduo enquanto ser humano. As injustiças, acusações e execuções sem fundamentos também estão presentes nesses sistemas. Um grande exemplo que pode ser apontado diz respeito ao massacre do Carandiru ${ }^{42}$, onde dezenas de presos foram sumariamente condenados à morte por agentes estatais, sendo em muitos casos tais penas injustamente aplicadas e sem nenhuma equivalência aos delitos praticados pelos presidiários mortos.

É evidente que com a população buscando agir com suas próprias mãos, desrespeitando as garantias constitucionais, além do retorno da vingança privada, o que pode ser observado também é o total rompimento com o sistema acusatório, que, de acordo com o ensinamento de Renato Brasileiro de Lima, "caracteriza-se pela presença de partes distintas, contrapondo-se acusação e defesa em igualdade de condições, e a ambas se sobrepondo um juiz de maneira equidistante e imparcial" 43 , e a volta do temível sistema inquisitorial, que tem como "característica principal o fato de as funções de acusar, defender e julgar encontrarem-se concentradas em uma única pessoa, que assume assim as vestes de um juiz acusador, chamado de juiz inquisidor" "44, sendo inevitavelmente fonte de injustiças visto que o "juiz fica ligado psicologicamente ao resultado da demanda, perdendo a objetividade e a imparcialidade no julgamento." ${ }^{45}$. Ainda é pior nos sistemas penais paralelos e subterrâneos, visto que quem atua no papel de juiz se trata normalmente de uma pessoa sem qualquer conhecimento jurídico, e além de julgar, acusar e defender, este "juiz" também executa a pena.

A insegurança jurídica causada por tais sistemas penais é gritante, ninguém mais se vê na certeza de enfrentar um devido processo legal caso seja suspeito de algum crime e, na medida em que seja acusado,

\footnotetext{
${ }^{42}$ https://super.abril.com.br/historia/como-foi-o-massacre-do-carandiru/

${ }^{43}$ LIMA, Renato brasileiro de. Manual de processo penal: volume único. 4. Ed. Salvador: JusPODVIM, 2016. p. 39.

44 op. cit., p. 38 , nota 37.

45 _. op. cit., p. 38, nota 37.
} 
frequentemente a condenação é imediata, sumária e absurdamente desproporcional ao suposto dano causado.

Desta maneira ficam evidentes as consequências que o uso exagerado do valor simbólico do Direito Penal pode causar, principalmente no que diz respeito ao fortalecimento dos sistemas penais paralelos e subterrâneos. Neste aspecto é válido o ensinamento de Andrade:

Utilizar o Direito Penal como simbologia para atender os clamores populares não só acaba por retirar do cidadão suas liberdades individuais, como causa descrédito no sistema, o que pode acabar por levar a legitimação, pela população, de toda sorte de abusos por parte das esferas punitivas e persecutórias do Estado. ${ }^{46}$

Após todos os aspectos abordados aqui, conclui-se que são evidentes as mazelas causadas ao Direito brasileiro, além de inúmeras afrontas à Constituição Federal, a execução dos sistemas penais paralelos e subterrâneos são fontes de injustiças, fazendo com que inocentes paguem o preço de falsas promessas dos governantes e do medo enfrentado pela sociedade.

\section{CONCLUSÃO}

Após todo o exposto no presente artigo, resta evidente a interrelação entre o mau-uso do Direito Penal Simbólico e o surgimento e fortalecimento dos sistemas penais paralelos e subterrâneos.

Com o uso exacerbado do valor simbólico do Direito Penal como único meio ao combate da criminalidade, propagado pela mídia, acentuado pela sociedade de risco e globalização e explorado pelos discursos políticos, o Direito Penal como um todo acaba perdendo sua legitimidade como instrumento para a execução do jus puniendi estatal.

A população, ao retirar esta legitimidade do Direito Penal a toma para si própria, buscando executar o jus puniendi por seus próprios meios, nascendo deste modo os sistemas penais paralelos e subterrâneos.

${ }^{46}$ ANDRADE, André Lozano. op. cit., p. 114, nota 3. 
Tais sistemas penais, geralmente atuam fora de qualquer legalidade, gerando enormes injustiças e consequências desastrosas para a sociedade e o Direito como um todo.

Por estas razões, é que se deve ter um especial cuidado ao se utilizar do valor simbólico do Direito Penal, por mais que este possa ser benéfico à justiça, principalmente no que tange à prevenção negativa, seu uso desmedido e desvirtuado pode trazer muitas outras consequências maléficas, além das elencadas neste artigo.

\section{REFERÊNCIAS}

ANDRADE, André Lozano. Os problemas do direito penal simbólico em face dos princípios da intervenção mínima e da lesividade. Revista Liberdades, n. 17, p. 99-117, set./dez. 2014. Disponível em: <http://www.revistaliberdades.org.br/site/outrasedicoes/outrasedicoesexibir.php?rcon_id=214>.Acesso em: 10 ago. 2017.

BARROS, Flávio Augusto Monteiro de. Direito penal, parte geral: v. 1. 4. ed. São Paulo: Saraiva, 2004.

BRASIL. Constituição (1988). Constituição da República Federativa do Brasil. Disponível em: <http://www.planalto.gov.br/ccivil_03/constituicao/constituicaocompilado.htm>. Acesso em set. 102017.

Código Civil (2002). Lei n 10.406 de janeiro de 2002. Disponível em: <http://www.planalto.gov.br/ccivil_03/leis/2002/L10406.htm>. Acesso em set. 102017.

GALDI, Juliana Quintino Vieira. A Sociedade do Risco e o Direito Penal Simbólico. Revista Direito Mackenzie, [S.L], v. 8, n. 1, p. 39-50, 2014. Disponível em: <http://editorarevistas.mackenzie.br/index.php/rmd/article/view/7451>. Acesso em: 10 ago. 2017.

JUNIOR, Aguinaldo Ferreira Do Nascimento. Direito penal simbólico: a ineficiência do sistema penal contemporâneo. Revista JurES, [S.L.], v. 8, n. 16, p. 112-122, 2016. Disponível em: <http://revistas.es.estacio.br/index.php/juresvitoria/article/view/572>.Acesso em: 10 ago. 2017.

NORONHA, E. Magalhães. Direito Penal: $1^{\circ}$ Volume. 2. Ed. São Paulo: Saraiva, 1963.

NUCCI, Guilherme de Souza. Manual de Direito Penal: parte geral: parte especial. 9. Ed. São Paulo: Editora Revista dos Tribunais, 2013.

LIMA, Renato brasileiro de. Manual de processo penal: volume único. 4. Ed. Salvador: JusPODVIM, 2016.

SANTOS, Juarez Cirino Dos. Direito penal: parte geral. 6 ed. Curitiba: ICPC Cursos e Edições, 2014. P. 454 
SALIM, Alexandre; AZEVEDO, Marcelo André De. Direito penal - parte geral. 7 ed. Salvador: JusPODVIM, 2017. P. 37

TOLEDO, Kelvia De Oliveira; ASSIS, Claudio Abel Franco De. O simbolismo penal e a deslegitimação do poder punitivo na sociedade de risco: consequências e imprecisões. Revista de criminologias e políticas criminais, Minas Gerais, v. 1, n. 2, p. 238 - 266, jul./dez. 2015. Disponível em: <http://www.indexlaw.org/index.php/revistacpc/article/view/42>.Acesso em: 10 ago. 2017.

ZAFFARONI, Eugenio Raul; ALAGIA, Alejandro; SLOKAR, Alejandro. Derecho Penal - Parte General. $2^{a}$ Edição. Buenos Aires: Ediar Sociedad Anónima Editora, 2002. 